\title{
Development of acute leukaemia after idiopathic myelofibrosis
}

\author{
JM Hernández, JF San Miguel, M González, A Orfao, MC Cañizo, C Bascones, J \\ Hernández, A López Borrasca
}

\begin{abstract}
Aims: To determine the characteristics of blastic transformation of idiopathic myelofibrosis.

Methods: The clinical and haematological features, as well as the morphological characteristics of blast cells, were analysed in nine adults with blast transformation.

Results: Most of the patients were male and had enlarged spleens and livers. Five of the patients had normal platelet counts, while all had pronounced anaemia and a moderate degree of leucocytosis. The duration of the acute phase was usually short: 16 (SD 8) weeks. Most myeloid cell lineages-granulocytic, monocytic, and megakaryocytic-were similarly distributed. One patient also had a hybrid (lymphoid-myeloid) phenotype. The morphological assessment of blast cells agreed with immunophenotyping in five out of the nine cases. The onset of the blastic phase was not related to previous treatment.
\end{abstract}

Conclusions: A pluripotential stem cell with preferential myeloid commitment would be the target cell of blast transformation in idiopathic myelofibrosis. Our immunophenotypic data do not support the concept of a preferential association between megakaryocytic lineage and the acute transformation of idiopathic myelofibrosis. The absence of previous treatment in some cases suggests that this kind of evolution is part of the natural history of idiopathic myelofibrosis.

Idiopathic myelofibrosis is a clonal myeloproliferative disorder that is characterised by an abnormal deposition of collagen material in bone marrow, extramedullary haematopoiesis, splenomegaly, and a leucoerythroblastic blood picture. ${ }^{1-3}$ The clinical course of the disease is extremely variable, with a median survival from diagnosis of between one and five years. ${ }^{13-5}$ Between $5 \%$ and $20 \%$ of patients with primary idiopathic myelofibrosis develop a terminal blastic phase. ${ }^{6-8}$ These acute leukaemias, if following clinically confirmed idiopathic myelofibrosis, should not be confused with a rare syndrome described by Lewis and Szur': acute myelofibrosis. This is characterised by the absence of splenomegaly, pancytopenia, hypercellular bone marrow with severe fibrosis, and blast cell infiltration. The blast cells in acute myelofibrosis have fre- quently been identified as megakaryoblasts, this picture thus being considered by several authors as synonymous with acute megakaryoblastic leukaemia -M7-. ${ }^{10-12}$

Little attention has been paid to analysing the characteristics of the acute leukaemic transformation in idiopathic myelofibrosis. ${ }^{67}$ Moreover, the nature of the blast cells in these leukaemias has usually been studied by conventional morphological and cytochemical techniques, ${ }^{6}$ and only occasionally by immunophenotypic analysis. ${ }^{13-17}$ Although most of these reports concern individual cases, they suggest that all cell lineages may be affected: myelomonocytic, ${ }^{6}$ megakaryocytic, ${ }^{13-15}$ erythroid $^{16}$ and lymphoid. ${ }^{17}$

The aim of our study was to analyse the clinical and haematological characteristics of a series of nine patients with leukaemia secondary to idiopathic myelofibrosis, paying special attention to the nature of the blast cells.

\section{Methods}

Between 1984 and 1990, nine adult patients in idiopathic myelofibrosis blast transformation were studied at the University Hospital of Salamanca. Chronic idiopathic myelofibrosis was diagnosed from the following criteria: splenomegaly, a leucoerythroblastic blood picture, teardrop poikilocytes on peripheral blood smears, and hypocellular bone marrow with a pronounced fibrosis. ${ }^{6}$ Other disorders that could have a similar clinical picture as well as cases with concomitant polycythaemia vera were specificially excluded. Diagnosis of acute transformation was based on the presence of more than $30 \%$ blast cells in peripheral blood, or bone marrow, or both. ${ }^{18}$ Complete response was defined as the elimination of blast cells with a return to a chronic phase of idiopathic myelofibrosis both in peripheral blood and bone marrow.

Peripheral blood and bone marrow smears were stained with May-Grünwald-Giemsa and cytochemical methods for peroxidase, nonspecific sterases (naphtol AS-D acetate esterase or $\alpha$-naphtyl acetate esterase, both with and without sodium fluoride inhibition), periodic acid Schiff and $\alpha$-naphtyl butyrate esterase.

In all nine patients mononuclear cells were isolated from peripheral blood by FicollHypaque density gradient centrifugation when acute transformation was diagnosed. The median number of blast cells in the specimens studied was $57 \%$ (ranging from $31 \%$ to $92 \%$ ). The cells were analysed by indirect immunofluorescence with a terminal deoxynucleotidyl 
Table 1 Clinical and biological characteristics of acute leukaemia following idiopathic myelofibrosis

\begin{tabular}{ll}
\hline Previous chronic phase in months (range) & $26(24)(4-71)$ \\
Age & $65(12)(45-80)$ \\
Sex $=$ male & $78 \%$ \\
Systemic symptoms & $56 \%$ \\
Anaemic syndrome $\dagger$ & $34 \%$ \\
Bone pain & $11 \%$ \\
Hepatomegaly & $78 \%$ \\
Splenomegaly & $89 \%$ \\
Lymphadenopathies & $33 \%$ \\
Haemoglobin $(\mathrm{g} / \mathrm{dl})$ & $6 \cdot 8(2)(4 \cdot 8-9 \cdot 6)$ \\
White cell count $\left(\times 10^{9} / 1\right)$ & $26(17)(5-54)$ \\
Platelets $\left(\times 10^{9} / 1\right)$ & $101(99)(10-320)$ \\
Percentage of bone marrow infiltration & $77(17)(55-95)$ \\
\hline
\end{tabular}

Results expressed either as means (SD) or percentage of positive cases.

$\star$ Systemic symptoms: weight loss, anorexia, and weakness.

†Anaemic syndrome: severe fatigue and exertional dyspnoea.

transferase (TdT) heteroantiserum (Supertechs, Bethesda, Maryland, USA), and a panel of monoclonal antibodies whose reactivity and specificity have been described previously. ${ }^{19} 20$ For early myeloid cells the following monoclonal antibodies were used: My9 (CD33) and My7 (CD13); for granulocytic lineage, VIMD5 and FMC10 (CD15); for monocytic lineage, FMC17 and leuM3 (CD14); for megakaryoblasts, J15 (CD41, anti-GPIIb/IIIa), C17 (CD61, anti GPIIIa), FMC25 (CD42a, antiGPIX), and AN51 (CD42b, anti GPIb); for erythroid lineage, LICR LON.R10 (antiglycophorin A); for precursor cells, GRB1 (anti-HLA-DR), FMC56 (CD9); and for lymphoid lineage, B4 and leu12 (CD19), B1 (CD20), 3A1 (CD7), and J5 (CD10).

To minimise non-specific Fc receptor binding the cells were incubated at room temperature for 15 minutes with $A B$ serum to block the $F c$ receptor and washed in a buffer containing phosphate buffered saline-bovine serum albumin-AB serum. In all experiments the first antibody was omitted as a negative control, using irrelevant isotype-matched monoclonal antibodies. Cells were analysed either using an immunofluorescence microscope (Leitz Ortholux) or flow cytometry (FACScan BD, Mountain View, California, USA). For the assessment of a lineage, a minimum of $15 \%$ blast cells positive for one or more of the specific monoclonal antibodies was required. ${ }^{212}$ The presence of either one or two cell populations was assessed by appropriate individual dual stainings, as described previously. ${ }^{23} 24$

Table 2 Immunophenotypic and morphological classification of blastic transformation following idiopathic myelofibrosis

\begin{tabular}{|c|c|c|}
\hline Immunophenotype & $\begin{array}{l}\text { No of } \\
\text { patients }\end{array}$ & $\begin{array}{l}\text { Morphology and } \\
\text { cytochemistry }\end{array}$ \\
\hline $\begin{array}{l}\text { Undifferentiated } \\
(\text { HLA-DR }+, \text { CD13/33-, CD19-) }\end{array}$ & 1 & Myeloblastic (M2) \\
\hline $\begin{array}{l}\text { Myeloblastic } \\
\text { (CD13/33+, CD15-, CD14-) }\end{array}$ & 2 & $\begin{array}{l}\text { Myelomonocytic (M4) (1) } \\
\text { Monocytic (M5a) (1) }\end{array}$ \\
\hline $\begin{array}{l}\text { Myeloblastic with maturation } \\
\text { (CD13/33+, CD15 }+, \text { CD14-) }\end{array}$ & 2 & Myeloblastic (M2) \\
\hline $\begin{array}{l}\text { Monocytic (CD13/33+, CD15-, CD14+) } \\
\text { Mixed myeloid }\end{array}$ & 1 & Monocytic (M5b) \\
\hline $\begin{array}{l}\mathrm{CD} 13 / 33+, \mathrm{CD} 15+, \mathrm{CD} 41+, \text { Antiglyco } \mathrm{A}+ \\
\mathrm{CD} 13 / 33+, \mathrm{CD} 14+, \mathrm{CD} 1+ \\
\text { Hybrid (myeloid-lymphoid) } \\
(\mathrm{CD} 13 / 33+, \mathrm{CD} 14+, \mathrm{CD} 41+, \mathrm{CD} 19+, \mathrm{CD} 10+, \\
\mathrm{TdT}+\text { ) }\end{array}$ & $\begin{array}{l}1 \\
1 \\
1\end{array}$ & $\begin{array}{l}\text { MB/ER/MK } \\
\text { MB/ER/MK } \\
\text { Myelomonocytic (M4) }\end{array}$ \\
\hline
\end{tabular}

MB/ER/MK: myeloblastic, erythroid, and megakaryocytic.

\section{Results}

The most relevant clinicobiological features of acute transformations of idiopathic myelofibrosis are summarised in table 1 . The interval from the diagnosis of idiopathic myelofibrosis to the acute phase was usually short (median 20 months). Only four out of nine patients had been previously treated with alkylating agents, the duration of the chronic phase in this group of patients being longer than that of the remaining five cases (mean 28 (SD 23) $v 15$ (10) months). Most patients were male (78\%). The most frequent clinical findings of acute leukaemia at presentation were systemic symptoms (56\% of cases) (table 1). All but one patient had an enlarged spleen and $78 \%$ an enlarged liver. The haematological profile pointed to a relatively normal platelet count $\left(>100 \times 10^{9} / 1\right)$ in five out of the nine patients; by contrast, all cases had severe anaemia $(6.8(2) \mathrm{g} / \mathrm{dl})$. A pronounced bone marrow infiltration was generally observed, with a median of $77 \%$ blast cells (table 1 ). Because of the advanced age of the patients, only four were treated with aggressive chemotherapy; none of them achieved complete response. The duration of the acute phase in the whole series was 16 (8) weeks, ranging from four to 28 weeks (table 1).

The immunophenotypic distribution of the nine patients studied is shown in table 2 . In one case the blast cells only expressed HLA-DR antigens, this patient being regarded as a case of undifferentiated leukaemia. Pure myeloid blast cell proliferation was identified in five patients: two of them showed a myeloblastic phenotype $(\mathrm{CD} 13+/ 33+; \mathrm{CD} 15-$; CD14-), while in the remaining three cases the blast cells displayed either granulocytic $(\mathrm{CD} 15+)$ two cases, or monocytic $(\mathrm{CD} 14+)$ one case, antigenic differentiation. The coexistence of two or three myeloid cell components was detected in two patients. Finally, one case had a hybrid leukaemia in which monoblasts and megakaryoblasts coexisted together with lymphoblasts (TdT,$+ \mathrm{CD} 19+, \mathrm{CD} 10+)($ table 2).

Because the FAB criteria cannot be applied to secondary acute leukaemias, ${ }^{25}$ a descriptive morphological classification was used. The blast cells were assigned to one of the following possible cell lineages: myeloblastic; monocytic; erythroid; megakaryocytic; and lymphoid (table 2). Concordant findings with the immunophenotype of blast cells were achieved in five out of the nine cases. The discrepancies involved: (a) the patient with an undifferentiated phenotype showing Auer rods, who was therefore classified morphologically as a myeloblastic leukaemia; (b) the two patients with a myeloblastic phenotype that were considered on morphological and cytochemical grounds to have monocytic differentiation; and (c) the case of hybrid transformation in which the morphology identified neither the lymphoid nor the megakaryocytic component. It should be noted that the two cases of mixed myeloid leukaemias in which megakaryoblasts were detected $(\mathrm{CD} 61+, \mathrm{CD} 41+)$ were recognised morphologically. 


\section{Discussion}

Several studies have been devoted to analysing the most relevant characteristics of the blast transformation in chronic myelogenous leukaemia. ${ }^{21226-28}$ By contrast, few studies on acute transformation of a previous idiopathic myelofibrosis have been published. ${ }^{235-7}$ Moreover, only anecdotal cases have been reported concerning the immunophenotypic characteristics of blast cells in these acute leukaemias. ${ }^{162}$

The clinical features of our patients are consistent with those of the single series of acute leukaemia following idiopathic myelofibrosis, ${ }^{6}$ and most of the individual case reports. 5151629 As in our study, only half the patients had received previous treatment with alkylating agents or radiotherapy, ${ }^{3616}$ suggesting that the evolution into acute leukaemia might be part of the natural history of idiopathic myelofibrosis. Survival in these blast transformations is short ${ }^{5616}$; this is probably due to both the age of the patients and to the actual nature of these leukaemias.

To the best of our knowledge, this is the first series that includes an immunophenotypic analysis of proliferating blast cells in acute leukaemias following idiopathic myelofibrosis, together with their morphological characterisation. Some previous studies, using a morphological and cytochemical approach, have shown that these leukaemias are generally myeloblastic or myelomonocytic, ${ }^{6}$ but in some case reports the existence of megakaryocytic, ${ }^{13-15}$ erythroid, ${ }^{16}$ or lymphoid ${ }^{17}$ transformations has been suspected on morphological grounds, as was the case in our study. Our immunological data confirm that although a typical myeloid phenotype - granulocytic or monocytic - is the one most commonly detected, other cell lineages, such as megakaryocytic, erythroid, and even lymphoid, may also be involved in these leukaemias, leading to the existence of both mixed myeloid and hybrid transformations. Despite the relatively good correlation between the morphological and immunological studies of blast cells, our data suggest that the diagnosis and classification of blast cells in acute leukaemia following idiopathic myelofibrosis is better achieved by a combined morphological, cytochemical, and immunological approach.

Several studies have suggested that the megakaryocyte cell lineage may have an important role in the pathogenesis of idiopathic myelofibrosis. . $^{30}$ The fact that acute myelofibrosis has been considered synonymous with acute megakaryoblastic leukaemia ${ }^{1011}$ could also suggest a preferential role for megakaryocytic cell lineages in acute leukaemias following previous idiopathic myelofibrosis. Interestingly, megakaryoblastic proliferation was detected in three of our nine cases $(33 \%)$, this incidence being clearly higher than that found in the de novo acute myeloid leukaemias $(11 \%) .{ }^{19}$ However, it should be noted that the prevalence of megakaryoblastic transformation in other myeloproliferative disorders, such as chronic myeloid leukaemia is also high-23\% to $51 \% .^{21227}$ These data would therefore not confirm that there is a special association be- tween idiopathic myelofibrosis in blastic transformation and the megakaryocytic cell lineage. Moreover, the coexistence of several cell lineages, including the lymphoid, would additionally indicate a clonal pluripotent stem cell origin for this disorder.

Supported by Grants from the Fondo de Investigaciones Sanitarias de la Seguridad Social (89/0651-2) and the "Asociación Española contra el Cáncer"

1 Varki A, Lottenberg $R$, Griffith $R$, Reinhard E. The syndrome of idiopathic myelofibrosis. A clinicopathologic syndrome of idiopathic myelofibrosis. A clinicopathologic review with emphasis on the prognostic

2 Smith RE, Chelmowski MK, Szabo EJ. Myelofibrosis: a concise review of clinical and pathologic features and treatment. Am J Hematol 1988;29:174-80.

3 Hasselbach H. Idiopathic myelofibrosis: a clinical study of 80 patients. Am J Hematol 1990;34:291-300.

4 Rosenthal DS, Moloney WC. Myeloid metaplasia: A study of 98 cases. Postgrad Med J 1969;45:136-42.

5 Ward HP, Block MH. The natural history of agnogenic myeloid metaplasia (AMM) and a critical evaluation of its relationship with the myeloproliferative syndrome. Medicine 1971;50:357-420.

6 Silverstein MN, Brown AL, Linman JW. Idiopathic myeloid metaplasia: its evolution into acute leukemia. myeloid metaplasia: its evolution

7 Arch Intern Med 1973;132:709-12. between bone marrow in a case of agnogenic myeloid between bone marrow in a case of agnogenic myeloid
metaplasia developing blast crisis. Scand J Haematol metaplasia develo

8 McCarthy DM. Myelofibrosis: Prognostic factors and treatment. Br J Haematol 1988;69:295-8.

9 Lewis SM, Szur L. Malignant myelosclerosis. Br Med J 1963;2:472-7.

10 Bain BJ, Catovsky D, O'Brien M, Spiers ASD, Richards HGG: Megakaryoblastic leukaemia presenting as acute myelofibrosis-a study of four cases with the platelet peroxidase reaction. Blood 1981;58:206-13.

11 Den Ottolander GJ, Te Velde J, Brederoo P, et al. Megakaryoblastic leukaemia (acute myelofibrosis): A report of three cases. Br J Haematol 1979;42:9-20.

12 Bennet JM, Catovsky D, Daniel MT, et al. Criteria for the diagnosis of acute leukemia of megakaryocytic lineage (M7). Ann Intern Med 1985;103:460-5.

13 Marcus RE, Hibbin JA, Matutes E, Whittle N, Waterfield $M D$, Goldman JM. Megakaryoblastic transformation of myelofibrosis with expression of the c-sis oncogene. Scand J Haematol 1986;36:186-93.

14 Choatte JJ, Domenico DR, McGraw TP, Farced J, Molnar Z, Schumacher HR. Diagnosis of acute megakaryoblastic leukemia by flow cytometry and immunoalkaline phosphatase techniques. Am J Clin Pathol 1988;89:247-53.

15 Jacobs P, Le Roux I, Jacobs L. Megakaryoblastic transformation in myeloproliferative disorders. Cancer 1984; 54:297-302.

16 Garcia S, Miguel A, Miguel A, Linares M, Navarro M, Colomina P. Idiopathic myelofibrosis terminating in Colomina P. Idiopathic myelofibrosis termina

17 Polliack A, Prokocimer M, Matzner Y. Lymphoblastic leukemic transformation (lymphoblastic crisis) in myelofibrosis and myeloid metaplasia. Am J Hematol 1980; 9:211-20.

18 Canellos GP. Clinical characteristics of the blast phase of chronic granulocytic leukemia. Hematol Oncol Clin North Am 1990;4:359-68.

19 San Miguel JF, González M, Cañizo MC, et al. Leukemias with megakaryoblastic involvement: Clinical, hematologic, and immunologic characteristics. Blood 1988;72: 402-7.

20 San Miguel JF, Ojeda E, Gonzalez M, et al. Prognostic value of immunological markers in acute myeloblastic leukemia. of immunological markers

21 Bettelheim P, Lutz D, Majdic O, et al. Cell lineage heterogeneity in blast crisis of chronic myeloid leukaemia. heterogeneity in blast crisis of ch

22 San Miguel JF, Tavares de Castro J, Matutes E, et al. Characterization of blast cells in chronic granulocytic leukaemia in transformation, acute myelofibrosis and undifferentiated leukaemia. $\mathrm{Br} J$ Haematol 1985;59: 297-309.

23 San Miguel JF, González M, Cañizo MC, Anta JP, Zola H, López-Borrasca. Surface marker analysis in acute myeloid leukaemia and correlation with FAB classification. $\mathrm{Br} J$ Haematol 1986;64:547-60.

24 San Miguel JF, Hernández JM, González-Sarmiento R, et al. Acute leukemia following a primary myelodysplastic characteristics. Blood 1991;78:768-74.

25 Bennet JM, Catovsky D, Daniel MT, et al. Proposals for the classification of the acute leukaemias. Br J Haematol 1976;33:451-8.

26 Janossy G, Woodruff RK, Pippard MJ, et al. Relation of 
"lymphoid" phenotype and response to chemotherapy incorporating vincristine-prednisolone in the acute phase of $\mathrm{Ph}$ positive leukemia $\mathrm{Cancer} 1979 ; 43: 426-34$.

27 Griffin JD, Todd III RF, Ritz J, et al. Differentiation patterns in the blastic phase of chronic myeloid leukemia. Blood 1983;61:85-91.

28 Kantariian HM, Keating MJ, Talpaz M, et al. Chronic myelogenous leukemia in blast crisis. $A m \mathrm{~J} \mathrm{Med}$ 1987;83:445-54.

29 Pereira A, Cervantes F, Montserrat E, Rozman C. Mielofibrosis primaria: descripción de una serie de 53 pacientes. Med Clin (Barcelona) 1989;92:521-5.
30 Groopman JE. The pathogenesis of myelofibrosis in myeloproliferative disorders. Ann Intern Med 1980;

31 Castro-Malaspina $H$, Rabellino EM, Yen A, Nachman RL, Moore MAS. Human megakaryocyte stimulation of proliferation of bone marrow fibroblasts. Blood 1981;57:781-7.

32 Castro-Malaspina H. Pathogenesis of myelofibrosis: Role of ineffective megakaryopoiesis and megakaryocyte components. In: Berk PD, Castro-Malaspina $\mathrm{H}$, Wasserman LR, eds. Myelofibrosis and the biology of connective tissue. New York: Alan R Liss, Inc, 1984. 